\title{
Local use of front and backyard medicinal species - a comparative study in six Latin American cities
}

\author{
I. M. Madaleno \\ Department of Natural Sciences, Portuguese Tropical Research Institute, \\ Portugal
}

\begin{abstract}
Native trees and medicinal herb species are essential components in Latin American front and backyards. They can be found as hedges and flourishing bushes in gardens, in small vases on terraces and balconies, in vacant urban plots, in peripheral lots and farms. They constitute a valuable resource for lowincome residents and alternative medicine for many. Central markets and weekly fairs additionally provide a wide variety of species used in mild or chronic diseases therapies, broadly appreciated by Latin American citizens. This comparative study was carried out in Lima (Peru), Santiago (Chile), Belem (Brazil), Havana (Cuba), San José (Costa Rica) and Mexico City (Mexico) for over a decade. The objective of the present ethno-geographic study is to analyze traditional ecological knowledge both because garden biodiversity preservation is crucial for a healthy urban environment and because traditional healing practices and ethno-botanical knowledge are an important legacy for future generations.
\end{abstract}

Keywords: natural resources, local knowledge, Latin America.

\section{Introduction}

A fundamental part of the Portuguese Tropical Research Institute's (IICT) work has consisted of investigation of ancestral traditions still followed in indigenous communities today. The medicinal plants research has been focused on a set of traditional healing techniques, using herbal preparations disseminated at 
international congresses, workshops and seminars, and made available to the general public online, by means of virtual exhibitions at www.iict.pt.

Because the Portuguese legislation (2003) allows the unconventional therapies to be an option available for the whole Portuguese population, under strict public health regulations and the Ministry of Health control, the Institute has sought to correspond the general public's increasing interest in natural medicine and other treatment alternatives, under the scope of multidisciplinary work involving geographers, botanists, historians, anthropologists and agronomists, directed to tropical research.

\section{Methods}

The sources of data were a sample of 929 inquiries to urban gardeners, periurban farmers and medicinal herb traders, obtained during the exploration of front and backyards, through examination of cultivated plots located in peripheral neighbourhoods, as well as journeying central markets, local fairs and trading posts, places where less wealthy Latin Americans look for relief in the case of health afflictions or when seeking to mitigate chronic diseases. Additionally, several interviews have been conducted in the six metropolitan areas, aimed at selected inquired gardeners and traders as well as to traditional healers, and plant therapists, totalling 150 actors (see table 1). Qualitative research included video records of particular interviewed traditional healers and urban gardeners, sometimes together with their flourishing gardens. All the investigated plant species have been photographed so as to permit easier dissemination of results to the scientific community and to the general public.

Besides the half a dozen cities and metropolitan areas that were investigated, however, the traditional medicinal knowledge research included rural settings and wider regions: 1) The quest started in Belem (Brazil) in 1998, with a survey of urban agriculture (555 inquiries) within the municipality [1], and has evolved in 1999 to Presidente Prudente (280 questionnaires), S. Paulo state [2]. In 2005, another scientific mission to the Lower Amazon River has added 15 extensive interviews to Belem and Barcarena herb traders and plant therapists; 2) Urban Agriculture research has been continued in Santiago (Chile) from 2002 to 2005 [3], with an extension to Easter Island in 2006, because native Rapanui previously interviewed at La Pintana municipality (south of Santiago) steered our curiosity further away; 3) The Mexican Central Metropolitan Region was investigated in 2004 (Mexico City Federal District and the Popocatepetl volcano slopes, in Mexico state) and in 2006 (Cuernavaca, Morelos state and Puebla); 4) Lima the capital city of Peru has been researched in 2006, either. The Peruvian mission included visits to Cuzco and MachuPichu, in order to examine ancestral Incan practises and integrate them better in current Quechua Indian healing traditions; 5) For identical reasons, missions to the Chilean Aymara Indian territory were vital to better understand the ancestral usages of several Andean species in Santiago metropolis [4].

In April 2009 the Island of Cuba was the first Caribbean Sea setting targeted by the ongoing empirical research process and in July 2009 another scientific 
mission to San Jose (Costa Rica) further enriched the IICT's Latin American database [5], regarding traditional medicinal knowledge, inputting data obtained in a Central American country.

Local knowledge of plant biology has been sought together with the domestic prescriptions and other data related to its handling. In order to classify the medicinal plants the scientific denomination was obtained in publications of Agapito and Sung [6], in the case of Peru; Alonso et al. [7], as far as Mexican species are concerned; Cunha et al. [8], in the case of European plant species; Muñoz et al. [9], for southern (Mapuche Indian territory) Chilean taxa; Roig and Mesa $[10,11]$ publications to identify Cuban and in general Caribbean species; van den Berg manual [12] as her personal help was essential to identify Brazilian Amazon medicinal plants; and Villagrán and Castro [13] ethnographic study fundamental to recognise Aymara Andean taxa. Last but not least, Navas [14] has provided the scientific denominations for Central American species.

A summary of taxonomic and medicinal knowledge is provided in Table 1, which incorporates the top ranking species of those that have been researched in the field per country and metropolitan area. Common names are in Spanish, (with the exception of Brazil, which name is obviously Portuguese), exactly as they have been collected during the interviewing process, followed by the binomial that makes up the scientific name together with the abbreviation of those botanists who identified and classified the plant species.

Table 1: Medicinal species preferences in six Latin American metropolitan areas.

\begin{tabular}{|c|c|c|c|c|}
\hline $\begin{array}{l}\text { Metropolitan } \\
\text { Areas }\end{array}$ & $\begin{array}{l}\mathrm{N}^{\circ} \text { of inquiries } \\
\text { to urban } \\
\text { gardeners and } \\
\text { herb traders }\end{array}$ & $\begin{array}{l}\mathrm{N}^{\circ} \text { of } \\
\text { interviews to } \\
\text { selected } \\
\text { actors }\end{array}$ & $\begin{array}{l}\text { Common } \\
\text { name }\end{array}$ & $\begin{array}{l}\text { Scientific name of the } \\
\text { top ranking species }\end{array}$ \\
\hline $\begin{array}{c}\text { Central } \\
\text { Mexican } \\
\text { Region }\end{array}$ & 100 & 55 & Toronjil & $\begin{array}{c}\text { Agastache mexicana } \\
\text { kunth }\end{array}$ \\
\hline Lima & 34 & 38 & Manzanilla & $\begin{array}{c}\text { Matricaria } \\
\text { chamomilla } \mathrm{L} .\end{array}$ \\
\hline $\begin{array}{l}\text { Santiago } \\
\text { Metropolis }\end{array}$ & 132 & 25 & $\begin{array}{l}\text { Melisa or } \\
\text { Toronjil }\end{array}$ & Melissa officinalis L. \\
\hline $\begin{array}{l}\text { Metropolitan } \\
\text { area of Belem }\end{array}$ & 570 & 15 & Erva-cidreira & $\begin{array}{c}\text { Lippia alba (Miller) } \\
\text { HBK. }\end{array}$ \\
\hline Havana & 50 & 10 & Tilo & $\begin{array}{c}\text { Justicia pectoralis } \\
\text { Jacq. }\end{array}$ \\
\hline San José & 43 & 7 & Manzanilla & $\begin{array}{c}\text { Matricaria } \\
\text { chamomilla } \mathrm{L} .\end{array}$ \\
\hline
\end{tabular}

Source: Fieldwork data obtained during the 1998-2009 scientific missions.

\section{Results}

Research conducted in six Latin American countries has led to built-up a database containing over 400 plant species, some of them native and used as medicines for their healing properties. Domestic prescriptions constitute the bulk 
of the research results, using parts of plants cropped in gardens and cultivated fields by urban gardeners or then wild species collected from vacant plots and traded in or near markets by indigenous peasants.

Garden biodiversity preservation is crucial for a healthy urban environment: i) It increases urban food security. Empirical research developed in the municipalities of Belem, Brazil and La Pintana, Santiago, Chile, have shown that fruit trees are first and medicinal herbs second in front and backyards; ii) food grown in home gardens improve less wealthy household nutrition. In fact, 95\% of the cultivated plots visited in Belem and $87 \%$ in Presidente Prudente produced fruits whilst $22 \%$ in the first and $46 \%$ in the last Brazilian city had vegetable gardens; iii) surplus of food and medicinal species cultivated can generate income and reduce poverty, an important conclusion of the Mexican scientific missions; iv) because most urban gardeners have no income to buy chemical fertilizers and herbicides, there is notice of improved sanitation solutions and waste recycling, with frequent usage of compost; v) gardening improves physical and psychological health due to increased physical activity. The good physical state and conversation skills of over 60 year old urban gardeners was common to Havana, Cuba and Belém, Brazil; vi) the growth of medicinal species and the consumption of herbal remedies ameliorate chronic disease treatments and frequently resolves mild health problems, such as colds and diarrhea.

In spite of the diversity of local medicinal flora, research has shown that some European species occupy a top ranking position within the inquired and interviewed metropolitan populations. That was the case with Santiago, Chile, where Melisa was preferred to world known Chilean species such as Boldo (Peumus boldus (Mol.) Lyons); It was also the case with Lima, Peru and San José, Costa Rica, whose sample researched populations preferred Chamomile to the profusion of native remedies. Peruvian Muña (Minthostachys andina (Butler) Epling), for instance, (an old Incan herb that grows wild on the Andean slopes), is considered a very good analgesic and it is a very good antiseptic.

All top ranking medicinal plants are eclectic herbs easily grown in front and backyards that have mild activity as tranquilisers, preferred because they offer the possibility of diminishing the stress that afflicts most of the citizens. Common names date from the early years of colonisation and they either name a European species, as mentioned, or then they have baptised native species because the given name was that of a European species that possessed matching medicinal applications: Melisa is Toronjil, in Spain and Erva-Cidreira, in Portugal; Cuban Tilo has been given the common name of similarly utilized old world tree (Tilia europaea) even though it is a Caribbean half a metre herb.

Table 2 summarises just some of the most appreciated native medicinal species.

Maqui is a native southern Chilean tree frequently found in Santiago's urban gardens and periurban plots. Two leaves per cup of hot water are enough to generate anti-flu infusions, particularly recommended against sour throat. The sweet fruit is used to cure diarrhea. Mapuche Indians use them to produce chicha, an alcoholic drink. The active principles of the leaves recommend its 
Table 2: $\quad$ Native medicinal species selected in six Latin American countries.

\begin{tabular}{|c|c|c|c|c|}
\hline $\begin{array}{l}\text { Common name } \\
\text { and Country }\end{array}$ & Scientific name & $\begin{array}{l}\text { Species } \\
\text { characteri- } \\
\text { sation }\end{array}$ & $\begin{array}{c}\text { Plant part } \\
\text { used }\end{array}$ & $\begin{array}{l}\text { Medicinal } \\
\text { application }\end{array}$ \\
\hline $\begin{array}{l}\text { Maqui } \\
\text { (Chile) }\end{array}$ & $\begin{array}{c}\text { Aristotelia } \\
\text { chilensis (Mol.) } \\
\text { Stuntz } \\
\end{array}$ & Tree & $\begin{array}{c}\text { Leaves, } \\
\text { fruit }\end{array}$ & $\begin{array}{l}\text { Anti-bacterial, } \\
\text { anti-tumour, anti- } \\
\text { flu, diarrhoea }\end{array}$ \\
\hline $\begin{array}{l}\text { Canelo } \\
\text { (Chile) }\end{array}$ & $\begin{array}{l}\text { Drimys winteri } \\
\text { J.R. et G. Forster }\end{array}$ & Tree & $\begin{array}{c}\text { The whole } \\
\text { tree }\end{array}$ & $\begin{array}{l}\text { anti-scorbutic, } \\
\text { anti-rheumatic, } \\
\text { anti-septic, fever }\end{array}$ \\
\hline $\begin{array}{l}\text { Huamampinta } \\
\text { (Peru) }\end{array}$ & $\begin{array}{c}\text { Chuquiraga } \\
\text { huamampinta } \\
\text { Hieron }\end{array}$ & Bush & Leaves & $\begin{array}{c}\text { Anti-cancer, } \\
\text { diuretic, } \\
\text { conjunctivitis. }\end{array}$ \\
\hline $\begin{array}{l}\text { Flor Blanca } \\
\text { (Peru) }\end{array}$ & $\begin{array}{c}\text { Buddleja incana } \mathrm{R} \\
\text { e P }\end{array}$ & Small tree & $\begin{array}{c}\text { The whole } \\
\text { plant }\end{array}$ & $\begin{array}{c}\text { Diuretic, } \\
\text { Anti-septic }\end{array}$ \\
\hline $\begin{array}{l}\text { Asmachilca } \\
\text { (Peru) }\end{array}$ & $\begin{array}{l}\text { Aristeguietia } \\
\text { gayana (Wedd.) } \\
\text { King e Robinson }\end{array}$ & Herb & $\begin{array}{c}\text { Leaves and } \\
\text { sticks }\end{array}$ & $\begin{array}{l}\text { Asthma, anti- } \\
\text { cough, anti- } \\
\text { catarrh }\end{array}$ \\
\hline $\begin{array}{l}\text { Chicalotl } \\
\text { (Mexico) }\end{array}$ & $\begin{array}{c}\text { Argemone } \\
\text { mexicana L. }\end{array}$ & Herb & $\begin{array}{c}\text { The whole } \\
\text { plant }\end{array}$ & $\begin{array}{c}\text { Cataracts, scabies, } \\
\text { constipation }\end{array}$ \\
\hline $\begin{array}{c}\text { Lengua de Vaca } \\
\text { (Mexico) }\end{array}$ & $\begin{array}{c}\text { Rumex mexicanus } \\
\text { Meins. }\end{array}$ & Herb & Leaves & $\begin{array}{l}\text { Diuretic, anti- } \\
\text { inflammatory }\end{array}$ \\
\hline $\begin{array}{c}\text { Pariri } \\
\text { (Brazil) }\end{array}$ & $\begin{array}{c}\text { Arrabidaea chica } \\
\text { (Humb. and } \\
\text { Bonpl.) Verl. }\end{array}$ & Bush & Leaves & $\begin{array}{l}\text { Antianemic, } \\
\text { stomach ulcers, } \\
\text { anti-septic }\end{array}$ \\
\hline $\begin{array}{c}\text { Catinga de Mulata } \\
\text { (Brazil) }\end{array}$ & $\begin{array}{l}\text { Aeolanthus suavis } \\
\text { Mart. }\end{array}$ & Herb & Leaves & $\begin{array}{l}\text { Anti-flu baths, ear } \\
\text { infections }\end{array}$ \\
\hline $\begin{array}{c}\text { Manzanilla } \\
\text { Cubana } \\
\text { (Cuba) }\end{array}$ & $\begin{array}{c}\text { Isocarpha } \\
\text { atriplicifolia } \mathrm{R} . \\
\mathrm{Br} .\end{array}$ & Herb & Leaves & $\begin{array}{c}\text { Stomach aches, } \\
\text { diarrhoea, eye } \\
\text { infections }\end{array}$ \\
\hline $\begin{array}{c}\text { Guapinol } \\
\text { (Costa Rica) }\end{array}$ & $\begin{array}{l}\text { Hymenaea } \\
\text { courbaril L. }\end{array}$ & Tree & $\begin{array}{l}\text { Roots, bark, } \\
\text { leaves, fruit. }\end{array}$ & $\begin{array}{c}\text { Diabetes, } \\
\text { rheumatic pains, } \\
\text { diarrhoea, asthma }\end{array}$ \\
\hline $\begin{array}{l}\text { Hierba Mora } \\
\text { (Costa Rica) }\end{array}$ & $\begin{array}{c}\text { Solanum } \\
\text { americanum Mill. }\end{array}$ & Herb & $\begin{array}{l}\text { Leaves and } \\
\text { flowers }\end{array}$ & $\begin{array}{c}\text { Rheumatic pains, } \\
\text { analgesic }\end{array}$ \\
\hline
\end{tabular}

Source: Fieldwork data obtained during the 1998-2009 scientific missions.

ingestion in anti-tumour infusions. Skin applications in plasters and cataplasms are widely used for the native Chilean species has anti-bacterial properties.

Traditional knowledge of medicinal plants has been studied through identification of the active principles, meaning the chemical principles with healing properties. Having had no possibilities to have the collected plant species analysed, IICT team has sought to favour dissemination of species whose chemical properties have been recognized by local experts. In order to extract the active principles there are different ways of preparing medicinal plant species: 1. Infusions consist of steeping herbs in hot (not boiling) water; 2. Concoctions or decoctions are boiling extracts from stems, roots, barks and the time one should boil them makes the difference between prescriptions and therapies; 3. Macerations are water extracts where one lets chopped plant materials overnight. This procedure is recommended for plant juices extraction, and in the case of usage of roots and barks; 4. Syrups are preparations with smashed leaves or juices with sugar or honey, usually recommended as anti-cough and anti- 
catarrh; 5. Compresses and plasters as alcohol extracts are ways of preserving herbal medicines that are supposed to be used externally, through frictions or wrapped in a cloth and applied to the skin.

Canelo is the sacred tree of the Mapuche Indian population. Native in Southern Chile, it grows in Santiago's gardens and it is used to treat fever and against rheumatism. Canelo has proven anti-bacterial, anti-tumour and antiinflammatory principles [9]. The bark is anti-scorbutic for its rich content in vitamins. In neighbouring Peru, the biodiversity makes the choice of species quite difficult. Research has targeted mainly the trading posts for gardening is difficult in Lima, located on a coastal desert area. The endemic Andean species Huamampinta, (that grows wild above 3000 metres), is consumed to prevent prostate cancer. For those who do not ingest the concoction regularly, it is recommended a concoction of a handful of Huamampinta leaves together with Achiote (Bixa orellana L.) in the case of bladder and prostate problems. When diagnosed prostate cancer, Uña de Gato (Uncaria tomentosa (Willd) de Candolle) should be added to Huamampinta and Achiote, generating a powerful mix of three anti-tumoural herbs. This concoction should be taken daily. A known and statistically established fact is the longevity of Peruvian males that sometimes outlive the women.

Peruvian Quechua prescriptions are gendered and one of the most recommended endemic species is Flor Blanca used from the time of the Incas to regulate the cycle of fertility. The small tree grows wild from 2000 to 4000 metres, up the Andes Mountains, and it is a good diuretic, solely used by women, because men should ingest Andean Huamampinta or the Amazon Rainforest native Achiote.

Asmachilca is another Andean endemic species that grows above 3000 metres consumed among the Aymara Indians to control asthma attacks as the Spanish word suggests. The Aymara descend from Tiwanakota peoples that dominated the Andean Mountains long before the Incas. Aymara Indians inhabit southern Peru, Northern Chile, Western Bolivia and Northern Argentina. Their medicinal practices, usually male dominated, are some of the most rewarding to research for they not only use local species but cover a wide range of diseases with more botanical knowledge than superstition.

Chicalotl is a beautiful Mexican herb whose leaves are steeped in water generating infusions to counteract diarrhea. Some healers recommend its usage to wash out the eyes in the case of conjunctivitis; however, pharmacological tests have proven it irritates the mucous membranes (Fig. 1). The seeds are ingested in concoctions against constipation or applied in plasters to treat scabies. They are sold in Mexico City's Sonora central market and in Cuernavaca, Morelos state. The latex was used to treat cataracts during the Aztec period. The root is still used, boiled in water for ten minutes and applied in hair washing to counteract baldness. Lengua de Vaca is another native Mexican species that took a similar European herb (Rumex crispus L.) designation. The leaves are ingested in diuretic concoctions, which are part of Nahua Indian traditions. Boiled leaves are also used in plasters on skin inflammations because of the species recognized anti-inflammatory principles. Lengua de vaca is grown in Mexico City and Cuernavaca (Morelos) front and backyards (see Fig. 2). 


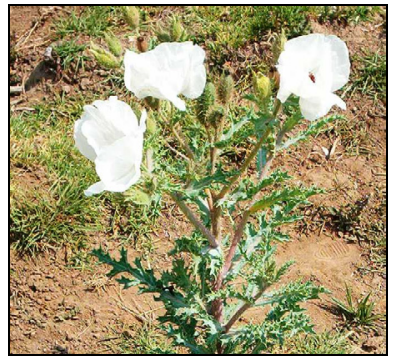

Figure 1: Chicalote or Chicalotl Aztec medicinal species (Mexico State).



Figure 2: Lengua de Vaca, Nahua medicinal species (Morelos State).

The Amazon Region is one of the most biodiverse settings in the world. Native species, some of which endemic, have been extensively researched by the IICT for they were found in Belem's gardens. Pariri is one of the species classified by Humboldt and Bonpland. Infusions of its leaves are recommended to treat anaemia, ingested in the case of stomach ulcers and indigestion. The species is also used to heal uterine infections and applied in plasters to heal scars. Catinga de Mulata is an aromatic herb used in anti-flu baths. The plant leaves are smashed and the juice is used as ear drops to mitigate pain by less wealthy households. Ingestion should be avoided because the species is toxic.

In Cuba, front and backyard biodiversity is essential to mitigate aches and treat wounds. Cuban Chamomile is a highly effective analgesic. Its single use is recommended to wash out the eyes in the case of conjunctivitis, or combined with Quita Dolor (Lippia alba), and ingested to counteract stomach aches, indigestion and diarrhoea. Because Cuban families lack financial resources to buy cosmetics, several young Cuban mothers declared to apply a concoction of Cuban Chamomile in the case of baby rashes.

Central American tropical forests present a wide variety of species traded in San José markets on a daily basis. Guapinol is a tree that possesses wide range of medicinal applications. The leaves and branches have anti-asthmatic virtues, the bark and leaves are ingested in anti-diabetic concoctions, the fruit is antirheumatic, and the roots, bark and leaves are consumed in concoctions and macerations to treat diarrhoea. Hierba Mora is a tropical American herb grown in San José front and backyards. Common name is identical to the European, but the American species is abundant in Costa Rica used in analgesic concoctions and anti-rheumatic frictions as alcohol extract.

\section{Discussion}

The discovery of the Americas and the colonisation period led by the Portuguese and Spanish peoples, during and after the sixteenth century, set of a process of mutual learning even though not always of understanding and of acceptance of native American plant therapies. Codices, namely Father Bernardino de Sahagún [15] and the renowned Badiano [16], as well as de Oviedo's [17] Natural History 
have enriched European medicine with North and Central American native species. As for South America, Antonio de Ulloa has extensively documented native medicinal flora in a manual first edited in Barcelona [18]. The healing properties of the prolific plant species of the Amazon basin have been comprehensively documented by Ferreira [19] in the eighteenth century during his remarkable expedition sponsored by the Portuguese crown. The work of the German father of modern Geography - Alexander von Humboldt - who explored South America together with the French botanist Aimé Bonpland further inspired Charles Darwin to see the interconnections between various aspects of nature [20]. The botanical remains recovered by archival research that reveals certain plants to have been used both as part of the diet as for traditional indigenous therapeutic practises.

Taro (Colocasia esculenta (L.) Schott), for instance, is preferred to potatoes, maize (the staple food in Chile) or rice in Easter Island gastronomy. Rapanui residing in Santiago continue the Easter Island tradition of not only accompanying fish or meat with Taro but also of using the tuber as medicine. It has recognised anti-inflammatory principles and it is particularly recommended for bowels problems. The tuber is also smashed and mixed with honeybee and applied in anti-rheumatic cataplasms.

In most researched indigenous cultures life and death, sickness and health are situations of balance or of imbalance. The role of traditional healers is that of restoring lost balances. Current research focused particularly the healing practices meant to restore health balances through the usage of medicinal plant species. Investigations targeted mainly domestic remedies because they constitute a repository of experience and tradition the IICT aims to disseminate as a legacy to future generations, under the scope of unconventional therapeutic options. The objectives are to promote garden biodiversity preservation in the cities and to provide the general public alternative ways to resolve health problems.

\section{Conclusions}

Latin American cities are expanding fast mostly due to migration from rural areas. Attracted by job opportunities, better services and leisure, the newcomers do not always fulfil their dreams and consequently they have to seek for alternative strategies to food insecurity, scarcity of employment and social stress. What happens when one cannot afford the pharmacy bills [21]? The answer is low-income urban residents grow medicinal species in front and backyards, in vacant urban plots, in small vases on terraces and balconies, in peripheral lots and farms. Medicinal species can also be purchased in central markets and weekly fairs, which are more accessible to the urban poor than conventional pharmaceutical drugs. With the exception of Chile, the countries investigated offer free public health care systems. They are however short in medicines supply. Traditional healing practises and ethno-botanical knowledge are essential treatment alternatives for urban households living below the poverty line. 


\section{References}

[1] Madaleno, I.M. Urban Agriculture in Belém, Brazil. Cities, 17 (1), Oxford: Pergamon Press/Elsevier, United Kingdom, 2000, 73-77.

[2] Madaleno, I.M. Urban Agriculture in Brazil. A tale of two cities. Trialog 65 (2), 2000, 24-27.

[3] Madaleno, I.M. \& Gurovich, A. "Urban Versus Rural” no Longer Matches Reality: endurance of an early public agro-residential development in periurban Santiago, Chile. Cities, 21 (6), Oxford: Elsevier Science, United Kingdom, 2004, 513-526.

[4] Madaleno, I.M. The Privatisation of Water and its Impacts on Settlement and Traditional Cultural Practises in Northern Chile. Scottish Geographical Journal, 123 (3). London: Routledge, United Kingdom, 2007, 193-208.

[5] Madaleno, I.M. Arca de Noé Florida: Saberes e Práticas Medicinais da América Latina. Workshop Plantas Medicinais e Fitoterapêuticas nos Trópicos. Lisboa: IICT/CCCM, 2009.

http://www2.iict.pt/archive/doc/I_Madaleno_wrkshp_plts_medic.pdf

[6] Agapito, T. \& Sung, I. Fitomedicina I y II. Lima: Editora Isabel, 2004.

[7] Alonso, C. M, Ochoa, F. L, Rodriguez, B. E \& Essayag, R. M. Plantas Medicinales en México II: composición, usos y actividad biológica. México, UNAM, 1999.

[8] Cunha, A.P, da Silva, A.P \& Roque, O.R. Plantas e Produtos Vegetais em Fitoterapia. Lisboa, Fundação Calouste Gulbenkian, 2003.

[9] Muñoz, O., Montes, M \& Wilkomirsky, T. Plantas Medicinales de Uso en Chile: Química y Farmacología. Santiago, Universitaria, 2004.

[10] Roig Y. \& Mesa, J. T. Plantas Medicinales Aromáticas o Venenosas de Cuba. Ciencia y Técnica, Habana, Cuba, 1974.

[11] Roig Y. \& Mesa, J.T. Diccionario Botánico de Nombres Vulgares Cubanos. Ministerio de Cultura: Habana, Cuba, 1988 (vol. 1 and 2).

[12] Van den Berg, M.E. Plantas Medicinais na Amazónia. Belém, Museu Paraense Emílio Goeldi, 1993.

[13] Villagrán, C \& Castro, V. Ciencia Indígena de los Andes del Norte de Chile. Santiago, Universitaria, 2004.

[14] Navas, H.R. La Utilidad de las Plantas medicinales en Costa Rica. Heredia, Euna, 2007.

[15] Sahagún, B. de. "Historia General de las Cosas de Nueva España”, 1548 (archives of the Museum of Medicine, Mexico City).

[16] Badiano, J. Libellus de Medicinallbus Indorum Herbis, 1552 (archives of the Museum of Medicine, Mexico City).

[17] Fernández de Oviedo, G. Sumario de la Natural Historia de las Indias. Madrid: Dastin, 2002 (the original is in Spain, at Escorial Library and dates from 1546).

[18] Ulloa, A. Viaje a la América Meridional. Madrid: Dastin, volumes I and II, 2002 (first edited in Barcelona in 1748).

[19] Simon, W.J. Scientific Expeditions in the Portuguese Overseas Territories (1783-1808). IICT, Lisboa, 1983. 
646 The Sustainable City VI

[20] Bondre, N. Darwin on the rocks. Nature Geoscience, 2 (10), 2009, 668-669.

[21] Madaleno, I.M. What happens when one cannot afford the Pharmacy bills? Comparative study of medicinal plant consumption in Latin America. Pharmacologyonline, 1, Salerno: University of Salerno, Italy, 2006, 6-14. http://www.unisa.it/download/1966_145_1162986346_4MadalenoNewsletter.pdf 